\title{
TETRAPLODON ANGUSTATUS (BRYOPSIDA, SPLACHNACEAE) IN THE POLISH TATRA MTS
}

\author{
BEATA CYKOWSKA-MARZENCKA
}

\begin{abstract}
The paper gives six new records of the rare coprophilous altimontane moss species Tetraplodon angustatus (Hedw.) Bruch \& Schimp. from the Polish Tatra Mts in the Western Carpathians. The ecology and current distribution of the species in the Tatras are described.
\end{abstract}

Key words: mosses, Tetraplodon angustatus, distribution, ecology, Tatra National Park, Tatra Mts, Carpathians, Poland

Beata Cykowska-Marzencka, Laboratory of Bryology, Institute of Botany, Polish Academy of Sciences, Lubicz 46, 31 -512 Kraków, Poland; e-mail: b.cykowska@botany.pl

\section{INTRODUCTION}

Tetraplodon angustatus (Hedw.) Bruch \& Schimp. is a rare altimontane coprophilous moss (Fig. 1), one of six Tetraplodon species in Europe (Hill et al. 2006) and one of two species of the genus in Poland (Ochyra et al. 2003; Stebel et al. 2004; Cykowska 2005). Recently it was discovered at six localities in the Polish part of the Tatras in the Western Carpathians.

Tetraplodon angustatus is a boreal-montane species with an almost continuous circumpolar range in the Holarctic. The northern limit of the species corresponds to the north treeline, with a few localities farther north (Szmajda et al. 1991). It occurs in Europe, Asia and North America; the global distribution of T. angustatus was discussed in detail and mapped by Szmajda et al. (1991).

In Europe, Tetraplodon angustatus occurs in Fennoscandia, extending eastwards through the Kola Peninsula to the Ural Mountains; in the British Isles it was reported from the mountains of Scotland and North Wales. In continental Europe the species occurs mainly in the subalpine and alpine belts of the Alps and Carpathians, and in old mountains of the Variscan orogeny such as the Sudetes, Góry Świętokrzyskie Mts, and Rhön in Germany (Szmajda et al. 1991).

In Poland, Tetraplodon angustatus is a rare component of the montane moss flora, previously recorded only from the Sudetes (Limpricht 1867, 1930; Milde 1869; Berdowski 1974), and Góry

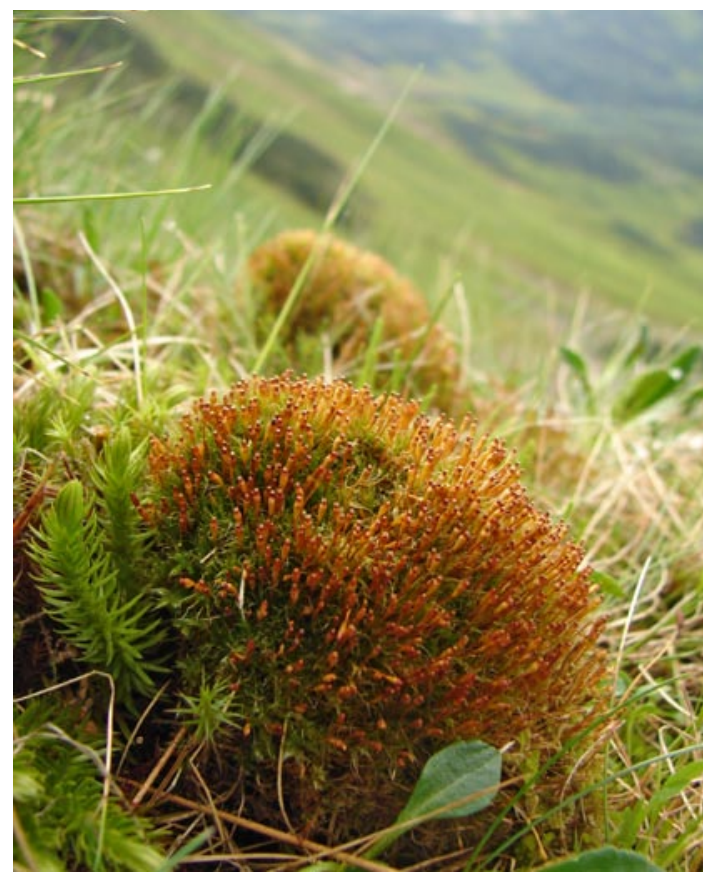

Fig. 1. Tetraplodon angustatus (Hedw.) Bruch \& Schimp. at Pyszniańska Przełęcz pass in the West Tatra Mts, 9 June 2007. 
Świętokrzyskie Mts (Kobendza 1939; Szmajda et al. 1991), and from the Western Carpathians (Stebel et al. 2004) where it was reported from seven localities in the Tatra Mts (Szmajda et al. 1991), three localities in the Kotlina OrawskoNowotarska basin (Staszkiewicz 1958; Lisowski 1961; Stebel et al. 2004) and one on the Babia Góra massif (Limpricht 1873, 1876; Stebel 2000).

Here I provide six new records of Tetraplodon angustatus in the Tatra Mts, present the current distribution of the species in the Tatras, and discuss its ecology. The herbarium material is deposited in the Bryological Herbarium of the W. Szafer Institute of Botany, Polish Academy of Sciences in Kraków (KRAM).

\section{ECOLOGY}

Tetraplodon angustatus is a coprophilous and nitrophilous moss growing on decaying animal carcasses, animal droppings, bird pellets, decaying wood, and nitrogen-rich soil or humus (Cameron \& Wyatt 1986; Dierssen 2001). It occurs on wellinsolated, moderately wet to moderately dry sites with moderately acid to neutral soils having $\mathrm{pH}$ 5.7-7.0(-7.5). It prefers natural sites under weak or no anthropopression, and tolerates cold microsites (Diersen 2001). In Europe T. angustatus is an indicator species in coprophilous communities belonging to the alliance Splachnion lutei Hadač \& Klika in Klika \& Hadač ex v. Hübschm. 1957, order Splachnetalia lutei Hadač \& Klika in Klika \& Hadač ex v. Hübschm. 1957 and class Funarietea hygrometricae v. Hübschm. 1957 (Diersen 2001). It is an entomophilous species which produces abundant sporophytes and spores dispersed by dipterans (Cameron \& Wyatt 1986). All the new collections in the Polish Tatra Mts reported here had mature sporophytes. They were found mainly on animal droppings; only one specimen was found on soil (probably nitrogenrich), and one specimen was found growing on a Sphagnum-Polytrichum hummock (Cykowska 2011; Cykowska-Marzencka 2013). All specimens occurred at open, well-insolated and moderately wet sites above the upper forest limit at 1630 $1960 \mathrm{~m}$ a.s.l.

\section{DistribUtion IN TATRA NATIONAL PARK}

In Tatra National Park, Tetraplodon angustatus was previously known from seven localities (Chałubiński 1886; Krupa 1888; Lisowski 1959, 1965; Szmajda et al. 1991). It was first reported more than a hundred years ago from three localities in the West Tatra Mts: the Dolina Chochołowska valley below Wołowiec, Mt. Starorobociański, and the Kasprowa Dolina valley (Chałubiński 1886). Later Lisowski (1965) reported it from the edge of Siwy Wierch peak and from the adjacent Przełęcz Palenica pass, but these two places are in the Slovak part of the West Tatras. The highest locality reported for T. angustatus in the West Tatras, $2000 \mathrm{~m}$ a.s.1., is the northern slope of Mt. Starorobociański Wierch (Lisowski 1965). During recent research it was found 40 meters lower (1960 m a.s.1.) on the western slope of Mt. Kamienista. Currently T. angustatus is known from 13 sites in the Polish part of Tatra National Park (Fig. 2).

New localities. SOUTHERn POLAND, WeSTERn CARPATHIANS, High Tatra Mts: Mt. Opalony Wierch, above Usypisty Piarg scree, alt. $1750 \mathrm{~m}$, $49^{\circ} 12^{\prime} 41^{\prime \prime} \mathrm{N} / 21^{\circ} 03^{\prime} 32^{\prime \prime} \mathrm{E}, \mathrm{N}$ slope, on animal dropping on soil and granite scree, c. spor., ATMOS grid square Ge60, 15 July 2005, leg. B. Cykowska 3420 (KRAM); West Tatra Mts: Mt. Smreczyński Wierch, on north traverse of the mountain, alt. $1940 \mathrm{~m}, 49^{\circ} 12^{\prime} 20^{\prime \prime} \mathrm{N} / 19^{\circ} 52^{\prime} 46^{\prime \prime} \mathrm{E}$, alpine belt, $\mathrm{N}$ aspect, on animal dropping, c. spor., ATMOS grid square Gd-69, 9 June 2007, leg. B. Cykowska 8703 (KRAM); W slope of Mt. Kamienista, alt. 1960 m, $49^{\circ} 11^{\prime} 47^{\prime \prime} \mathrm{N} / 19^{\circ} 51^{\prime} 54^{\prime \prime} \mathrm{E}$, alpine belt, W aspect, on animal dropping, c. spor., ATMOS grid square Gd-69, 9 June 2007, leg. B. Cykowska 8701 (KRAM); NW slope of Mt. Kamienista, alt. 1940 m, 49 $11^{\prime} 51^{\prime \prime} \mathrm{N} / 20^{\circ} 02^{\prime} 02^{\prime \prime} \mathrm{E}$, alpine belt, on Sphagnum-Polytrichum hummock, c. spor., ATMOS grid square Gd-69, 9 June 2007, leg. B. Cykowska 8701 (KRAM); below Pyszniańska Przełęcz pass, alt. $1700 \mathrm{~m}, 49^{\circ} 11^{\prime} 52^{\prime \prime} \mathrm{N} / 19^{\circ} 51^{\prime} 25^{\prime \prime} \mathrm{E}$, subalpine belt, $\mathrm{N}$ aspect, on animal dropping with Tetraplodon mnioides, c. spor., ATMOS grid square Gd-69, 9 June 2007, leg. B. Cykowska 8699 (KRAM); Mt. Grześ, alt. $1630 \mathrm{~m}, 49^{\circ} 14^{\prime} 11^{\prime \prime} \mathrm{N} / 19^{\circ} 46^{\prime} 04^{\prime \prime} \mathrm{E}, \mathrm{E}$ slope, on wet soil with Festuca supina, c. spor., ATMOS grid square Gd-58, 31 Aug. 2005, leg. B. Cykowska 5047 (KRAM).

ADDITIONAL SPECIMENS EXAMINED. SOUTHERN POLAND, WESTERN CARPATHIANS, High Tatra Mts: Mt. 


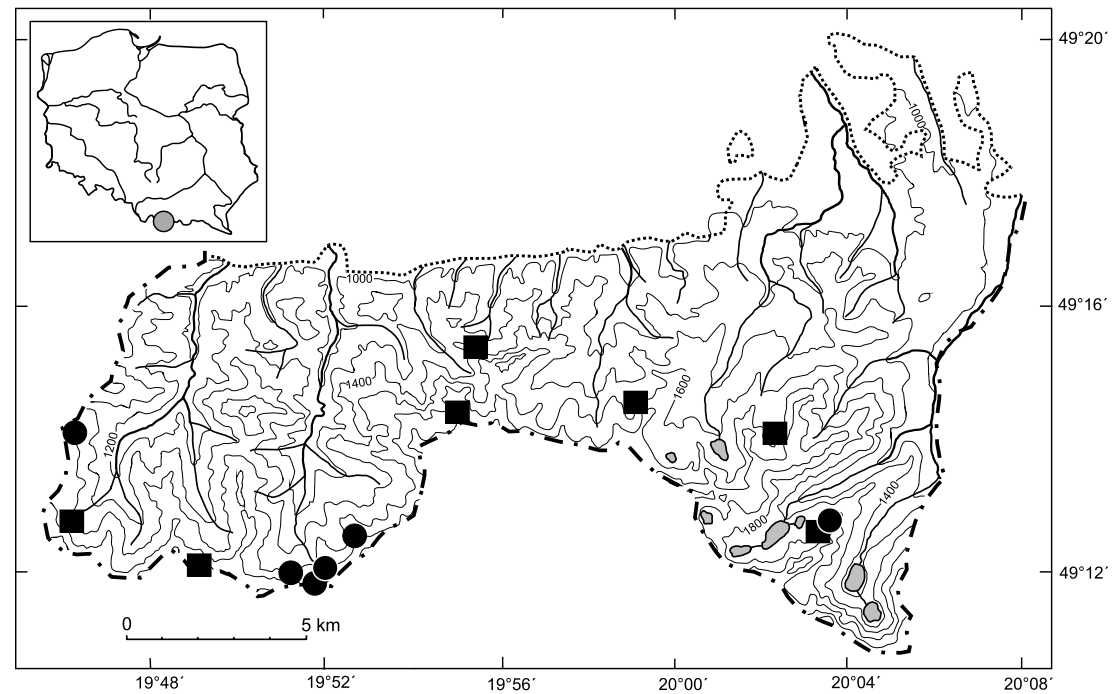

Fig. 2. Distribution of Tetraplodon angustatus (Hedw.) Bruch \& Schimp. in Tatra National Park $\mathbf{a}-$ previous stations; $\bullet-$ new localities.

Opalony Wierch, N slope, c. spor., ATMOS grid square Ge-60, 7 June 1956, leg. S. Lisowski 93182 (KRAM); West Tatra Mts: Kasprowa Dolina valley, upper forest belt, on granite boulder, ATMOS grid square Ge-50, 16 Sept. 1882, leg. T. Chatubiński (KRAM); Dolina Pańszczyca valley, cirque below Mt. Buczynowe Turnie, alt. 1930 m, ATMOS grid square Ge-50, 19 July 1957, leg. S. Lisowski 93183 (KRAM); Mt. Mały Giewont between Mała Dolina valley and Przełęcz Bacug pass, alt. $1500 \mathrm{~m}$, S exposition, on calcareous rocks, ATMOS grid square Gd-59, 15 July 1986, leg. J. Wójcicki s.n. (KRAM); Chochołowska Dolina valley, in upper part below Mt. Wołowiec, ATMOS grid square Gd-68, 14 July 1877, leg. T. Chatubiński s.n. (KRAM). SLOVAKIA, WESTERN CARPATHIANS, West Tatra Mts: edge of Siwy Wierch peak, alt. 1780 m, 14 Aug. 1964, leg. S. Lisowski 57535 (KRAM); Siwy Wierch range, near Przełęcz Palenica pass, alt. 1580 m, 14 Aug. 1964, leg. S. Lisowski 93181 (KRAM).

\section{DISCUSSION}

Tetraplodon angustatus is a rare component of the Polish moss flora. Most of its stations have been known since the $19^{\text {th }}$ century. In the Gory Świętokrzyskie Mts and the Polish Carpathians it was recorded also in the second half of the $20^{\text {th }}$ century and recently (Stebel 2000; Stebel et al. 2004; Stebel et al. 2013). The discovery of the new localities reported here suggests that it may be more common in the Tatra Mts, and future field work should yield additional localities (cf. Szmajda et al. 1991). In the Polish Carpathians, especially in the Tatras, $T$. angustatus seems not to be threatened. Only in the Sudetes all the records of the species except one date from the $19^{\text {th }}$ century. Its scarce occurrence in the Sudetes indicates that T. angustatus needs special attention, preferably inclusion on the local Red List of mosses as rare (R) (Żarnowiec et al. 2004).

ACKNOWLEDGEMENTS. I am grateful to Professor Ryszard Ochyra (Kraków) and Professor Adam Stebel (Sosnowiec) for their very helpful suggestions on the manuscript, and to Dr. Paweł Skawiński, Director of Tatra National Park, for his kind permission to carry out bryological research in the Park. This work was funded in part by the Polish Ministry of Science and Higher Education (grant no. N N303 572038), and by the statutory fund of the W. Szafer Institute of Botany of the Polish Academy of Sciences.

\section{REFERENCES}

BERDOWSKI W. 1974. Moss flora and bryophyte communities of the Ślęża massif. Monogr. Bot. 45: 1-126 (in Polish with English summary). 
CAMERON R. G. \& WyatT. R. 1986. Substrate restriction in entomophilous Splachnaceae: Role of Spore Dispersal. Bryologist 89(4): 279-284.

CHAŁUBIŃSKI T. 1886. Enumeratio muscorum frondosorum tatrensium, hucusque cognitorum. Pamiętnik Fizyjograficzny, Dziat 3 (Botanika. Zoologija) 6: i-viii + 1-207 + Tab. 1.

Cykowska B. 2005. Tetraplodon mnioides (Bryopsida, Splachnaceae) in the Tatra National Park (Poland). Polish Bot. J. 50(2): 159-161.

CYKowsKa B. 2011. Bryophytes of Sphagnum-Polytrichum hummocks in the Polish Tatra Mountains. In: A. STEBEL \& R. OCHYRA (eds), Chorological studies in the Polish Carpathians, pp. 233-259. Sorus, Poznań.

CYKowsKa-MarzencKA B. 2013. Taxonomy diversity and distribution of bryophytes in Polish Carpathians Cephalonella spinipera (Lindb.) Warnst. Acta Biol. Cracov., Ser Bot. 55(Suppl. 1): 41.

DIERSSEN K. 2001. Distribution, ecological amplitude and phytosociological characterization of European bryophytes. Bryophyt. Biblioth. 56: 1-289.

Hill M. O., Bell N., BRUgGeman-NANNENGa M. A., BruÉS M., Cano M. J., EnRoth J., Flatberg K. I., Frahm J.-P., Gallego M. T., Garilleti R., Guerra J., HedenÄs L., Holyoak D. T., Hyvönen J., IGNATOV M. S., LARA F., MAZimpaKa V., MuÑoz J. \& SÖDERSTRÖM L. 2006. An annotated checklist of the mosses of Europe and Macaronesia. J. Bryol. 28: 198-267.

KobendZa R. 1939. Les éboulis et leur rapport avec les forêts des montages de S-te Croix. Instytut Badawczy Lasów Państwowych, Rozprawy i Sprawozdania, Seria A 43: 1-76 (in Polish with French summary).

KRUPA J. 1888. Zapiski bryologiczne z Tatr i Przedtatrza. Sprawozdania Komisji Fizyjograficznej Polskiej Akademii Umiejętności 21: 65-94.

LIMPRICHT K. G. 1867. Beitrag zur bryologischen Kenntnis der grossen Schneegrube und der Kesselkoppe im Riesengebirge. Jahresber. Schles. Ges. Vaterl. Cult. 44: 139-146.

LiMPRICHT K. G. 1873. Nachträge zu J. Milde: Bryologica Silesiaca, 1869. Jahresber. Schles. Ges. Vaterl. Cult. 50: 27-224.

LiMPRICHT K. G. 1876. Laubmoose. In: F. COHN (ed.), Kryptogamen-Flora von Schlesien. 1: 27-224. J. U. Kern's Verlag (Max Müller), Breslau.

LIMPRICHT W. 1930. Die Pflanzenwelt der Schneegruben im Riesengebirde. Botanischen Jahrbüchern 63(3): 1-74 + 2 Karte.
LISOWSKI S. 1959. Materials to the bryoflora of the Tatra Mountains. Prace Komis. Bot. 21: 21-149 (in Polish with English summary).

LisowsKi S. 1961. Bryotheca polonica. Fasc. LIX. Nr 1501-1525. Musci convalle "Kotlina Nowotarska" (Carpati Occid.). Academia Scientarum Poloniae, Posnaniae.

LiSOWSKI S. 1965. Matériaux bryologiques des Tatras. Bull. Soc. Amis Sci. Lett. Poznań, Sér. D, Sci. Biol. 6: 123-146.

MiLdE J. 1869. Bryologia Silesiaca. Laubmoos-Flora von Nord- und Mittel-Deutchland, unter besonderer Berücksichtigung Schlesiens und Hinzunahme der Floren von Jütland, Holland, der Rheinpfalz, von Baden, Franken, Böhmen, Mähren und der Umgegend von München. A. Felix, Leipzig.

OCHYRA R., ŻARNOWIEC J. \& BEDNAREK-OCHYRA H. 2003. Census catalogue of Polish mosses. Polish Academy of Sciences, W. Szafer Institute of Botany, Kraków.

STASZKIEWICZ J. 1958. New locality of the moss Tetraplodon angustatus (Hedwig) Bryol. eur. in Poland. Fragm. Florist. Geobot. 4: 225-228 (in Polish with English summary).

SteBel A. 2000. Materiały do flory mchów masywu Babiej Góry (Karpaty Zachodnie). Parki Narodowe i Rezerwaty Przyrody 19: 43-54.

Stebel A., Parusel J. B. \& CisŁo G. 2004. Another locality for Tetrapodon angustatus (Bryopsida, Splachnaceae) in the Polish Carpathians. In: A. STEBEL \& R. OCHYRA (eds), Bryological studies in the Western Carpathians, pp. 75-78. Sorus, Poznań.

Stebel A., Rosadziński S., GóRski P., FoJCik B., RusińSKA A., VonĆINA G., SZCZEPAŃSKi M., Wilhelm M., Fudali E., PacioreK T., StaniaszeK-KiK M., Zubel R., Piwowarski B., Wolski G. J., Salachna A., SMolińSKA D. \& PIERŚCIŃSKA A. 2013. Contribution to the bryoflora of the Świętokrzyski National Park (Central Poland). Botanica Steciana 17: 75-82.

SZMAJdA P., BEDNAREK-OCHYRA H. \& OCHYRA. R. 1991. M. 294. Tetraplodon angustatus (Hedw.) Bruch \& Schimp. In: R. OCHYRA \& P. SZMAJDA (eds), Atlas of the geographical distribution of spore plants in Poland. Series V. Mosses (Musci). 7: 29-32 + 1 map. W. Szafer Institute of Botany of Polish Academy of Sciences, Kraków and Adam Mickiewicz University, Poznań.

ŻARnOwIEC J., STEBEL A. \& OChYRA. R. 2004. Threatened moss species in the Polish Carpathians in the light of a new Red-list of mosses in Poland. In: A. STEBEL \& R. OCHYRA (eds), Bryological studies in the Western Carpathians, pp. 9-28. Sorus, Poznań. 